\title{
The yield and grain quality of barley varieties in the northern forest steppe of the Tyumen region
}

\author{
Raisa Ivanovna Belkina*, Anatoly Yurievich Pershakov \& Vera Mikhailovna Gubanova \\ Biotechnology and Plant Breeding Department, Northern Trans-Ural State Agricultural University, Tyumen, 625 003, Russia \\ *Email: raisa-belkina@mail.ru
}

\section{ARTICLE HISTORY}

Received: 06 September 2020

Accepted: 03 February 2021

Published: 01 April 2021

\section{KEYWORDS}

Fertilizer backgrounds

Seed dresser

Growth regulators

Yield rate

1000 grains weight

Protein content

\begin{abstract}
Barley is cultivated mainly for feed purposes in the Tyumen region. At the same time, there is a need to obtain brewing barley grain. This research is aimed at establishing the influence of elements of cultivation technology on the productivity of barley varieties and identifying the compliance of grain quality indicators with the established requirements. The studies were performed in three field experiments on the experimental field of the of the Northern Trans-Ural State Agricultural University in the northern forest-steppe of the Tyumen region in 2014 - 2016. In terms of the complex indicator the collection of protein from a unit area - the Lamador Pro + Rostok variant stood out: for the Acha variety, this indicator was $612 \mathrm{~kg} / \mathrm{ha}$, for the Abalak variety $-646 \mathrm{~kg} / \mathrm{ha}$. The best indicators were obtained in the variant with the use of Hydromix complex for treating the seeds: for the Acha variety, the yield was $4.55 \mathrm{t} / \mathrm{ha}$, for the Abalak variety - $4.62 \mathrm{t} / \mathrm{ha}$, the protein content in the grain was 13.1 and $13.3 \%$, respectively. In terms of yield, Omsky 85 , Payjazz and Beatrice varieties surpassed the standard. The obtained research results are recommended for implementation at the enterprises of the agroindustrial complex of the Tyumen region.
\end{abstract}

\section{Introduction}

Among the grain crops in the country, barley (Hordeum vulgare L.) ranks second after wheat in terms of the cultivation area (1-3). In the Tyumen region of Russia, a significant part of the grain of this crop is used for feed purposes. The nutritional value of barley is ensured by the balanced amino acid composition of its protein, which allows introducing it into the diets for all types of animals, mostly for pig fattening $(4,5)$. The barley grains used for feed purposes must comply with a number of requirements, the most important of which is the protein content, it should be not less than $13 \%$ (6).

For assessing barley as a raw material for food purposes, the requirements include the following indicators: grain unit $\left(\geq 630 \mathrm{~g} \mathrm{l}^{-1}\right)$, humidity $(\leq 14.5 \%)$, weed impurity $(\leq 2 \%)$, grain impurity $(\leq 7 \%)$ and the share of small grains ( $\leq 5 \%)(7)$.

The regulated characteristics applied to the brewing barley grain include the protein content $(\leq 12$
$\%)$, the germination ability ( $\geq 90 \%)$ and the viability ( $\geq 95 \%$ ) (8).

The problem of creating highly productive barley varieties for the intended use and the development of effective technologies for their cultivation was described in several works by the scientists (5, 9-13). As a promising technique, presowing treatment of wheat and barley seeds with fungicides together with growth regulators and stimulants was considered. This element of technology had a positive effect on the growth, development of plants and in general, on the productivity of the crop (14-16).

Among the intensive technologies of grain crop cultivation, the methods with the use of micronutrient fertilizers have become widely used. Their use is aimed at stimulating the formation of chlorophyll in the leaves of the plants, improving the photosynthesis process, increasing the amount of the required substances, such as proteins, carbohydrates, amino acids etc. There is evidence that the use of micronutrient fertilizers increases the yield of crops

(C) Belkina et al (2021). This is an open-access article distributed under the terms of the Creative Commons Attribution License, which permits unrestricted use, distribution and reproduction in any medium, provided the original author and source are credited (https://creativecommons.org/licenses/by/4.0/).

To cite this article: Belkina R I, Pershakov A Y, Gubanova V M. The yield and grain quality of barley varieties in the northern forest steppe of the Tyumen region. Plant Science Today. 2021;8(2):229-235. https://doi.org/10.14719/pst.2021.8.2.943 
by $9.4-28.6 \%$ (17-19). The plants best absorb the chelated forms of micronutrient fertilizers. It is believed that their use compensates for the lack of microelements in the soil, such as boron, copper, iron, manganese etc. (20-22). The positive effects of chelated forms of fertilizers on the crop product quality have been established $(23,24)$. For cereals, microelements such as copper, zinc, boron, and molybdenum are mainly needed (25-28). The effectiveness of the micronutrient fertilizers increases upon their combined use for the seed and plant treatment (29).

In the Tyumen region, spring wheat showed the best productivity and profitability in the variants where the Hydromix complex of micronutrient fertilizers had been used for seed treatment, and the solution of the Master Special micronutrient fertilizers had been used for plant treatment $(30,31)$.

Barley grain is used in the brewing industry as the raw material for obtaining malt. In the Tyumen region, breweries use malt, as they do not have malting plants. At the same time, individual producers supply malting barley to other regions. The studies of the grain quality of various brewing barley varieties performed at the Northern TransUral State Agricultural University showed that the germination ability was the most limiting of all regulated parameters. The quality of the malt obtained from the grain of the Acha and Chelyabinsky 99 barley varieties was studied; its properties corresponded to the requirements of the second grade of the State Standard. The protein content in the grain of brewing varieties was close to the norm ( $\leq 12 \%)$ : in the Acha variety, the amount of protein varied from 11.2 to $12.3 \%$, depending on the growing conditions; in the Chelyabinsk 99 variety, it varied from 11.7 to $13.2 \%$ (32).

The basis for ensuring a certain level of productivity and product quality is the level of mineral nutrition. It is known that varieties respond to the mineral fertilizer background differently (18, $24,33)$. A particularly careful approach to calculating the fertilizer rates is needed in cultivating the brewing varieties of barley, as the protein content in its grains is limited (34).

The research was aimed at studying the influence of elements of cultivation technology on the productivity of barley varieties and identifying the compliance of grain quality indicators with the established requirements in the conditions of Northern Trans-Urals.

\section{Materials and Methods}

The studies were performed on the experimental field of the Northern Trans-Ural State Agricultural University in the northern forest-steppe of the Tyumen region in $2014-2016$. The soil of the experimental field was leached heavy loamy chernozem. In terms of the chemical composition, the arable soil layer was characterized by the medium humus content, the medium content of phosphorus and potassium, the low content of nitrogen and the slightly acidic reaction of the soil solution. The predecessors in the experiments were annual herbs.

\section{The research was performed in three field experiments:}

Experiment 1. Influence of presowing treatment of seeds with fungicide and growth regulators on yield and grain quality of barley varieties. Variants of the experiment provided for the treatment of seeds with Lamador Pro fungicide, Rostok and Mival-Agro growth regulators, and their combinations: 1) reference; 2) Lamador Pro (0.2 l/t); 3) Rostok (0.5 l/t); 4) Mival-Agro (5 gm/t); 5) Lamador Pro (0.2 l/t $)+$ Rostok (0.5 l/t); 6) Lamador Pro (0.2 l/t) + Mival-Agro ( $5 \mathrm{gm} / \mathrm{t})$. The studies were carried out on the Acha and Abalak barley varieties.

Experiment 2. Influence of treatment of seeds and plants with micronutrient fertilizers on yield and grain quality of barley varieties. In the variants of the experiment, Hydromix complex fertilizer and Master micronutrient fertilizer were used for processing of seeds and vegetative plants: 1) reference; 2) seed treatment with Hydromix, 100 gm per ton of seeds; 3) seed treatment with Hydromix, $100 \mathrm{gm} / \mathrm{t}+$ Master, 1 $\mathrm{kg} / \mathrm{ha}$ in the stem elongation phase; 4) seed treatment with Hydromix, $100 \mathrm{gm} / \mathrm{t}$ + Master, $1 \mathrm{~kg} / \mathrm{ha}$ in the heading phase; 5) seed treatment with Hydromix + Master, $1 \mathrm{~kg} / \mathrm{ha}$ in the phases of stem elongation and heading. The studies were carried out on the Acha and Abalak barley varieties.

Experiment 3. Study of productivity and grain quality of brewing barley varieties on different backgrounds of mineral fertilizers. Omsky 85, Payjazz, Baltika, Zhana, Beatrice brewing barley varieties were studied and compared with the Acha standard on two backgrounds of mineral fertilizers: moderate and elevated.

In experiments 1 and 2, the fertilizer rate was calculated by the balance method for yield of $4 \mathrm{t} / \mathrm{ha}$. In experiment 3 , moderate background was created by the application of fertilizers based on the grain yield of $4 \mathrm{t} / \mathrm{ha}$, while elevated background was created based on $5 \mathrm{t} / \mathrm{ha}$ grain yield.

The area of the experimental plots was $15 \mathrm{~m}^{2}$, the experiments were replicated four times, the placement of the plots was randomized. Field experiments, observations and calculations were performed in accordance with the Methodology for state variety testing of agricultural crops (35).

The grain yield was calculated by the method of direct threshing of grain from a plot using a SAMPO130 combine in the phase of full ripeness.

\section{In order to determine the grain quality indicators}

A combined grain sample from four replicates was used, laboratory analyses were performed twice.

The weight of 1000 grains was determined by counting the grains from average sample comprised of two samples of 500 grains each and weighing them on a laboratory balance with an accuracy of $0.01 \mathrm{gm}$. The sum of two samples was taken as the final result if the difference between them did not exceed 6\% (36). 
The grain unit was determined using a liter grainunit scale. The arithmetic mean of the two determinations was taken as the final result of the determination if the difference between them did not exceed 5 gm (37).

The barley grain uniformity was determined by sieving a sample of $100 \mathrm{gm}$ through sieves with the following dimensions: $2.8 \times 20 \mathrm{~mm}, 2.5 \times 20 \mathrm{~mm}, 2.2 \times 20$ $\mathrm{mm}$. Tailings were weighed on a laboratory balance with an accuracy of $0.01 \mathrm{gm}$. The final result of the determination was the largest sum of weighings obtained from two adjacent sieves, expressed as a percentage of the sample taken for analysis (36).

Protein content was determined by the Kjeldahl method for total nitrogen using a nitrogen to protein conversion factor of 6.25 (36).

The data were processed using the analysis of variance (38). Microsoft Excel application program was used for statistical processing of the data obtained.

\section{Meteorological conditions during the years of research}

Relative to the long-term average indicators characterizing the growing season of barley in the northern forest-steppe of the Tyumen region (average daily air temperature $15.3^{\circ} \mathrm{C}$, precipitation $200 \mathrm{~mm}$ ), the conditions of 2016 were especially different: the average daily air temperature exceeded the norm by $3.6{ }^{\circ} \mathrm{C}$ and the amount of precipitation was only $70 \%$ of the norm. However, it should be noted that precipitation was distributed relatively evenly during the growing season. In 2014 and 2015, the average daily air temperature slightly exceeded the long-term level (by 1.2 and $0.7 \circ \mathrm{C}$ ) and the amount of precipitation basically corresponded to the norm. Under such conditions, barley varieties were characterized by sufficiently high yield and good grain quality.

\section{Results}

The productivity of barley varieties in the experiment 1 where the seed treater and the growth regulators had been used for presowing treatment was within the calculated range of $4 \mathrm{t} \mathrm{ha}^{-1}$ and more (Table 1 ). For the Acha variety, the highest yield was obtained in the variant where the Lamador Pro seed treater had been used in combination with the Rostok growth regulator. A substantial increase by $0.37 \mathrm{t} \mathrm{ha}^{-1}$ was obtained in this variant.

Table 1. The yield of the barley varieties under the effect of the seed treatment with the seed treater and growth regulators, $\mathrm{t} \mathrm{ha}^{-1}$ (2014-2016).

\begin{tabular}{lcc}
\hline Variant & Acha & Abalak \\
\hline 1. Reference & 4.13 & 4.15 \\
\hline 2. Lamador Pro $\left(0.2 \mathrm{l} \mathrm{t}^{-1}\right)$ & 4.14 & 4.33 \\
\hline 3. Rostok $\left(0.5 \mathrm{l} \mathrm{t}^{-1}\right)$ & 4.06 & 4.42 \\
\hline 4. Mival-Agro $\left(5 \mathrm{~g} \mathrm{t}^{-1}\right)$ & 4.17 & 4.60 \\
\hline 5. Lamador Pro $\left(0.2 \mathrm{l} \mathrm{t}^{-1}\right)+$ Rostok $\left(0.5 \mathrm{l} \mathrm{t}^{-1}\right)$ & 4.50 & 4.55 \\
\hline 6. Lamador Pro $\left(0.2 \mathrm{lt}^{-1}\right)+$ Mival-Agro $\left(5 \mathrm{l} \mathrm{t}^{-1}\right)$ & 4.24 & 4.51 \\
\hline LSD $_{05}$ for the Variety factor & & 0.20 \\
\hline $\mathrm{LSD}_{05}$ for the Variant factor & & 0.34 \\
\hline
\end{tabular}

The Abalak variety showed responsiveness to the seed treatment with the Mival-Agro growth regulator, as well as to the combined seed treatment with the seed treater and growth regulators (variants four, five, and six). In these variants, the yield growth amounted to $0.45,0.40$ and $0.36 \mathrm{t} \mathrm{ha}^{-1}$ respectively.

Grain quality determines its customer value; therefore, studying the characteristics regulated by the state standards should be considered with regard to the varietal peculiarities and the growing conditions.

The physical properties of barley grain are characterized by such parameters as the weight of 1000 grains, the grain unit and the grain uniformity.

In the experiment, the weight of 1000 grains of the Acha variety amounted to 43.8 - 48.5 gm (Table 2). The highest values were noted in the reference variant and in the variant where the seeds had been treated with the Rostok product (48.1 and $48.5 \mathrm{gm}$ ). A significant decrease in the weight of 1000 grains was

Table 2. The physical properties of barley grain after the seed treatment with the seed treater and the growth regulators, 2014 2016 .

\begin{tabular}{|c|c|c|c|}
\hline Variants & $\begin{array}{c}\text { The } \\
\text { weight } \\
\text { of } 1,000 \\
\text { grains, } g\end{array}$ & $\begin{array}{c}\text { The } \\
\text { grain } \\
\text { unit, } \\
{\text { g l }{ }^{-1}}^{2}\end{array}$ & $\begin{array}{c}\text { The } \\
\text { unifor } \\
\text { mity, } \\
\%\end{array}$ \\
\hline \multicolumn{4}{|l|}{ Acha } \\
\hline 1.Reference & 48.1 & 640 & 90 \\
\hline 2.Lamador Pro $\left(0.2 \mathrm{l} \mathrm{t}^{-1}\right)$ & 47.2 & 643 & 93 \\
\hline 3.Rostok $\left(0.5 \mathrm{l} \mathrm{t}^{-1}\right)$ & 48.5 & 642 & 90 \\
\hline 4.Mival-Agro $\left(5 \mathrm{~g} \mathrm{t}^{-1}\right)$ & 47.5 & 640 & 94 \\
\hline 5.Lamador Pro $\left(0.2 \mathrm{lt}^{-1}\right)+\operatorname{Rostok}\left(0.5 \mathrm{lt}^{-1}\right)$ & 45.9 & 640 & 94 \\
\hline 6.Lamador Pro $\left(0.2 \mathrm{lt}^{-1}\right)+$ Mival-Agro $\left(5 \mathrm{lt}^{-1}\right)$ & 43.8 & 645 & 93 \\
\hline \multicolumn{4}{|l|}{$\begin{array}{ll} & \text { Abalak } \\
\end{array}$} \\
\hline 1.Reference & 47.0 & 620 & 92 \\
\hline 2.Lamador Pro $\left(0.2 \mathrm{lt}^{-1}\right)$ & 44.3 & 615 & 90 \\
\hline 3.Rostok $\left(0.5 \mathrm{lt}^{-1}\right)$ & 44.0 & 616 & 88 \\
\hline 4.Mival-Agro $\left(5 \mathrm{gt}^{-1}\right)$ & 47.8 & 615 & 89 \\
\hline 5.Lamador Pro $\left(0.2 \mathrm{lt}^{-1}\right)+$ Rostok $\left(0.5 \mathrm{lt}^{-1}\right)$ & 46.0 & 614 & 93 \\
\hline 6.Lamador Pro $\left(0.2 \mathrm{lt}^{-1}\right)+$ Mival-Agro $\left(5 \mathrm{lt}^{-1}\right)$ & 47.6 & 620 & 92 \\
\hline
\end{tabular}

noted in the variants where the seeds had been treated with both the seed treater and the growth regulators. For the Abalak variety, the highest value of the parameter was noted in the variant where the seeds had been treated with Mival-Agro (47.8 gm). A decrease in the weight of 1000 grains, compared to the reference, was observed in the variant where Lamador Pro had been used, and in variant three, where the seeds had been treated with the Rostok growth regulator.

The grain unit characterizes the value of barley as the raw material processed into groats, flour and other food products.

The grain density, which depends on the biological structure of the grain and its chemical composition, plays a significant role in assessing the grain unit. The normalized (basic) grain unit of barley should be not less than $580 \mathrm{~g} \mathrm{l}^{-1}$, and the grain unit of barley processed into groats should be $630 \mathrm{~g} \mathrm{l}^{-1}$ or more (7).

As shown by the data in Table 2, the Acha variety featured higher grain unit, compared to the Abalak 
variety. The average excess in the variants amounted to $25 \mathrm{~g} \mathrm{l}^{-1}$. Depending on the effect of the seed treatment with growth regulators and treaters, the Acha variety showed a tendency to increase the grain unit in the variants of the experiment, while the Abalak variety, on the contrary, showed a tendency to decrease the value of this parameter. As a whole, the grain units of the studied varieties were within the requirements for food barley grain.

The grain size uniformity is an important quality indicator. The more homogeneous the grain size is, or the more uniform it is, the lower the process losses are and the better the quality of the obtained products is. This applies to grain processing into flour, and especially - into groats. The requirements for groats barley envisage the grain uniformity of at least $85 \%$.

The grain of the studied barley varieties corresponded to the established norms for this parameter (Table 2). For the Acha variety, the grain uniformity was $90-94 \%$ and for the Abalak variety $-88-93 \%$.

The content of protein in the grain of the Acha variety was $13.6-14.7 \%$ in the variants of the experiment (Table 3). A slight increase in the value of this parameter (by $0.9 \%$ ), compared to the reference, was noted in the variant where the seeds had been treated with the seed treater. In the Abalak variety, an increase in the amount of protein in the grain was noted in all the studied variants $(0.5-0.9 \%)$.

Table 3. The protein content in the grains of the barley varieties after the seeds exposure to the seed treater and growth regulators, $\%(2014-2016)$.

\begin{tabular}{lrr}
\hline Variant & Acha & Abalak \\
\hline 1. Reference & 13.8 & 13.3 \\
\hline 2. Lamador Pro $\left(0.2 \mathrm{lt}^{-1}\right)$ & 14.7 & 14.2 \\
\hline 3. Rostok $\left(0.5 \mathrm{lt}^{-1}\right)$ & 13.8 & 13.9 \\
\hline 4. Mival-Agro $\left(5 \mathrm{gt}^{-1}\right)$ & 13.6 & 14.0 \\
\hline 5. Lamador Pro $\left(0.2 \mathrm{lt}^{-1}\right)+$ Rostok $\left(0.5 \mathrm{lt}^{-1}\right)$ & 13.6 & 14.2 \\
\hline 6. Lamador Pro $\left(0.2 \mathrm{lt}^{-1}\right)+$ Mival-Agro $\left(5 \mathrm{lt}^{-1}\right)$ & 14.0 & 13.8 \\
\hline
\end{tabular}

The highest protein yield in the Acha variety was obtained in the variant with the combined seed treatment with the seed treater and the Rostok growth regulator $\left(612 \mathrm{~kg} \mathrm{ha}^{-1}\right)$. For the Abalak variety, the same variant as well as the variant where the seeds had been treated with the Mival-Agro seed treater provided the best results $\left(646 \mathrm{~kg} \mathrm{ha}^{-1}\right.$ and 644 $\mathrm{kg} \mathrm{ha}^{-1}$ respectively).

According to the results obtained in experiment 2 (Table 4), it should be noted that significant increases in yield in the Acha variety were noted in all the studied variants $\left(0.28-0.38 t^{t} a^{-1}\right)$. Out of these variants, the best yields were noted in variant two, where the seeds had been treated with Hydromix (4.55 $\left.\mathrm{t} \mathrm{ha}^{-1}\right)$ and in variant three, where the seeds had been treated and the plants had received supplementary fertilizer at the phase of stem elongation $\left(4.52 \mathrm{t} \mathrm{ha}^{-1}\right)$. For the Abalak variety, the highest yield increase $\left(0.44 \mathrm{t} \mathrm{ha}^{-1}\right)$ was obtained in variant three, where the seeds had been treated with the Hydromix complex and the Master micronutrient fertilizer in the phase of stem elongation. The yields
Table 4. The yields of the barley varieties under the effect of seed and plant treatment with micronutrient fertilizers, $\mathrm{t} \mathrm{ha}^{-1}(2014-$ 2016).

\begin{tabular}{lrr}
\hline Variant & Acha & Abalak \\
\hline $\begin{array}{l}\text { 1. Reference } \\
\text { 2. Seed treatment, Hydromix }\end{array}$ & 4.17 & 4.28 \\
\hline $\begin{array}{l}\text { 3. Seed treatment, Hydromix + the Master } \\
\text { supplementary fertilizer in the phase of } \\
\text { stem elongation }\end{array}$ & 4.52 & 4.62 \\
\hline $\begin{array}{l}\text { 4. Seed treatment, Hydromix + the Master } \\
\text { supplementary fertilizer in the earing phase }\end{array}$ & 4.45 & 4.60 \\
\hline $\begin{array}{l}\text { 5. Seed treatment, Hydromix + the Master } \\
\text { supplementary fertilizer in the phase of } \\
\text { stem elongation and the earing phase }\end{array}$ & 4.48 & 4.40 \\
\hline $\begin{array}{l}\mathrm{LSD}_{05} \text { for the Variety factor } 0.20 \\
\mathrm{LSD}_{05} \text { for the Variant factor } 0.24\end{array}$ & & \\
\hline
\end{tabular}

in variant two, where the seeds had been treated with the Hydromix complex $\left(0.34 \mathrm{t} \mathrm{ha}^{-1}\right)$, and in variant four, where the seeds had been treated with the Hydromix complex and the plants received the Master supplementary fertilizer in the earing phase $\left(0.32 \mathrm{t} \mathrm{ha}^{-1}\right)$, also exceeded the yield in the reference variant.

The weight of 1000 grains of the Acha variety increased in the variants of the experiment, compared to the reference (Table 5). The highest value $(47.8 \mathrm{gm})$ was obtained in the variant where the seeds had been treated with the Hydromix complex and the plants had received the Master micronutrient fertilizer in the earing phase. For the Abalak variety, a reduction in the weight of 1000 grains was noted in the variants with supplementary fertilization in the earing phase.

Table 5. The weight of 1000 grains and the content of protein in the grains of the barley varieties under the effect of seed and plant treatment with micronutrient fertilizers, 2014-2016.

\begin{tabular}{|c|c|c|c|c|}
\hline \multirow[t]{2}{*}{ Variant } & \multicolumn{2}{|c|}{$\begin{array}{l}\text { The weight of } \\
1000 \text { grains, gm }\end{array}$} & \multicolumn{2}{|c|}{ Protein content, $\%$} \\
\hline & Acha & Abalak & Acha & Abalak \\
\hline 1. Reference & 45.7 & 48.9 & 12.2 & 12.7 \\
\hline $\begin{array}{l}\text { 2. Seed treatment, } \\
\text { Hydromix }\end{array}$ & 46.6 & 49.1 & 13.1 & 13.3 \\
\hline $\begin{array}{l}\text { 3. Seed treatment, } \\
\text { Hydromix + the Master } \\
\text { supplementary fertilizer } \\
\text { in the phase of stem } \\
\text { elongation }\end{array}$ & 46.3 & 49.1 & 13.2 & 13.3 \\
\hline $\begin{array}{l}\text { 4. Seed treatment, } \\
\text { Hydromix + the Master } \\
\text { supplementary fertilizer } \\
\text { in the earing phase }\end{array}$ & 47.8 & 46.9 & 13.3 & 13.5 \\
\hline $\begin{array}{l}\text { 5. Seed treatment, } \\
\text { Hydromix + the Master } \\
\text { supplementary fertilizer } \\
\text { in the phase of stem } \\
\text { elongation and the earing } \\
\text { phase }\end{array}$ & 46.5 & 47.5 & 13.5 & 13.6 \\
\hline
\end{tabular}

The protein content in the grains of barley increased in the variants where the grains had been treated with micronutrient fertilizers (Table 5). For the Acha variety, the increase amounted to $0.9-1.3$ $\%$ and for the Abalak variety - to $0.6-0.9 \%$.

The brewing barley varieties were studied on two backgrounds: the moderate one with the fertilizer norm intended for obtaining the yield of $3 \mathrm{t}$ $\mathrm{ha}^{-1}$, and the increased one with the fertilizer norm 
intended for obtaining the yield of $4 \mathrm{t} \mathrm{ha}^{-1}$ (Table 6). The highest yields were noted for the following varieties: Omsky 85 (the increase, compared to the standard, on the moderate background was $0.73 \mathrm{t}$ ha 1 , or $14 \%$ and on the elevated background $-0.49 t$ $\mathrm{ha}^{-1}$, or $\left.9 \%\right)$, Payjazz $\left(0.36 \mathrm{t} \mathrm{ha}^{-1}\right.$, or $7 \%$ and $0.27 \mathrm{t} \mathrm{ha}^{-1}$, or $5 \%$ respectively) and Beatrice $\left(0.50 \mathrm{t} \mathrm{ha}^{-1}\right.$, or $10 \%$ and $0.35 \mathrm{t} \mathrm{ha}^{-1}$, or $6 \%$, respectively). The highest responsiveness to the elevated background was noted in the Acha (the yield increase of $0.44 \mathrm{t} \mathrm{ha}^{-1}$ ) and Payjazz (+0.35 t ha $\left.{ }^{-1}\right)$ varieties.

Table 6. The effect of the mineral nutrition backgrounds on the productivity of the brewing barley varieties, 2014-2016

\begin{tabular}{|c|c|c|c|c|}
\hline \multirow[t]{2}{*}{ Variety } & \multicolumn{2}{|c|}{ Moderate background } & \multicolumn{2}{|c|}{ Elevated background } \\
\hline & t ha-1 & $\begin{array}{l}\% \text { to the } \\
\text { standard }\end{array}$ & t ha $^{-1}$ & $\begin{array}{l}\% \text { to the } \\
\text { standard }\end{array}$ \\
\hline $\begin{array}{l}\text { Acha, } \\
\text { standard }\end{array}$ & 5.05 & & 5.49 & \\
\hline Omsky 85 & 5.78 & 114 & 5.98 & 109 \\
\hline Payjazz & 5.41 & 107 & 5.76 & 105 \\
\hline Baltika & 4.51 & 93 & 4.44 & 81 \\
\hline Zhana & 4.89 & 97 & 4.78 & 87 \\
\hline Beatrice & 5.55 & 110 & 5.84 & 106 \\
\hline $\begin{array}{l}\mathrm{LSD}_{05} \text { for the } \\
\text { varieties }\end{array}$ & 0.31 & & & \\
\hline $\begin{array}{l}\mathrm{LSD}_{05} \text { for the } \\
\text { backgrounds }\end{array}$ & 0.24 & & & \\
\hline
\end{tabular}

An important feature of brewing barley is the grain size. It is believed that the grain with the weight of 1000 grains of at least $42 \mathrm{gm}$ is the best quality raw material for malt production (34).

The studied varieties on the moderate fertilizer background formed a fairly high value of the parameter: Acha - 48.5 gm, Omsky $85-45.4 \mathrm{gm}$, Payjazz - 45.8 gm, Baltika - 40.4 gm, Zhana - 48.2 gm and Beatrice - $50.5 \mathrm{gm}$. For the Baltika variety, this value reached the required level on the elevated fertilizer background - $42.0 \mathrm{gm}$. On the whole for the varieties, the effect of the elevated fertilizer background manifested itself in increasing the weight of 1000 grains by $1.3-2.2 \mathrm{gm}$.

The content of protein in the grains of brewing barley is considered optimal at a level of $9-12 \%$. The barley varieties with the protein content of less than $9 \%$ do not provide the necessary level of protein substances for yeast nutrition, forming stable foam and creating the beer taste, while the grain with higher protein content (above $12 \%$ ) heats greater upon malting and yields less stable and not always transparent beer (39).

The protein content in the grains of the studied barley varieties, on both the moderate and the elevated fertilizer backgrounds was virtually within the established requirements. On the moderate background, the amount of protein in the grain of the varieties was 8.6 - $9.9 \%$. The elevated background increased the protein content in the varieties by $0.8-$ $2.7 \%$. In this background, the protein content in the grain of the Acha variety reached $12.3 \%$, of the Omsky 85 variety - $10.3 \%$, of the Payjazz variety $9.8 \%$, of the Baltika variety $-9.9 \%$, of the Zhana variety $-10.2 \%$ and of the Beatrice variety -11.6 $\%$.

\section{Discussion}

The productivity of the barley varieties in the experiment where the seed treaters and growth regulators were used for presowing treatment has been within the calculated range of $4 \mathrm{t} \mathrm{ha}^{-1}$ and more. For the Acha variety, the yield has been the greatest when the Lamador Pro seed treater was used in combination with the Rostok growth regulator. The yield has reached $4.50 \mathrm{t} \mathrm{ha}^{-1}\left(+0.37 \mathrm{t} \mathrm{ha}^{-1}\right.$, compared to the reference). The Abalak variety has shown responsiveness to the seed treatment with the MivalAgro growth regulator as well as to the combined seed treatment with the seed treater and growth regulators. In these variants, the yield has reached $4.42-4.60 \mathrm{t} \mathrm{ha}^{-1}\left(+0.36-0.45 \mathrm{t} \mathrm{ha}^{-1}\right.$, compared to the reference). The highest protein yield in the Acha variety has been obtained in the variant with the combined seed exposure to the seed treater and the Rostok growth regulator $\left(612 \mathrm{~kg} \mathrm{ha}^{-1}\right)$. For the Abalak variety, the same variant as well as the variant where the seeds were exposed to the Mival-Agro seed treater provided the best results $\left(646 \mathrm{~kg} \mathrm{ha}^{-1}\right.$ and 644 $\mathrm{kg} \mathrm{ha}^{-1}$ respectively). The data obtained supplemented the information of scientists $(14,16)$ on the effectiveness of presowing seed treatment. At the same time, the responsiveness of seeds of the new Abalak variety to treatment with fungicide combined with growth regulators has been established.

In the experiment with the use of micronutrient fertilizers for the Acha variety, the variant with the seeds treated with the Hydromix complex (4.55 t ha-1) and the one with the seeds treated with the Hydromix complex and the Master micronutrient fertilizer in the phase of stem elongation (4.52 $\left.\mathrm{t} \mathrm{ha}^{-1}\right)$ have been the best. For the Abalak variety, the highest yield of $4.72 \mathrm{t} \mathrm{ha}^{-1}\left(+0.44 \mathrm{t} \mathrm{ha}^{-1}\right.$, compared to the reference) has been obtained in the variant with the seeds treated with the Hydromix complex and the Master micronutrient fertilizer in the phase of stem elongation. The protein content in the grains of barley has increased in the variants with the grains treated with micronutrient fertilizers. For the Acha variety, the increase has amounted to $0.9-1.3 \%$ and for the Abalak variety - to $0.6-0.9 \%$. In the zone of the northern forest-steppe of the Tyumen region, the use of microfertilizers was studied on spring wheat (30). Sufficiently high responsiveness of barley varieties to the use of micronutrient fertilizers both for presowing seed treatment and for spraying of vegetative plants has been shown.

In studying the varieties of brewing barley on various mineral nutrition backgrounds, it has been found that the most responsive to the elevated fertilizer background were the Acha (the yield increased by $0.44 \mathrm{t} \mathrm{ha}^{-1}$ ) and Payjazz (the yield increased by $0.35 \mathrm{t} \mathrm{ha}^{-1}$ ) varieties. The studied varieties feature a rather high weight of 1000 grains (42.0 - $51.2 \mathrm{gm})$, which characterizes them as the topquality raw material for malt production. The effect of the elevated fertilizer background has manifested itself in increasing the weight of 1000 grains by 1.3 $2.2 \mathrm{gm}$. The protein content in the grain of the studied barley varieties, on both the moderate and the elevated fertilizer backgrounds, has been virtually within the established requirements. The 
elevated background has increased the protein content in the varieties by $0.8-2.7 \%$. On this background, the protein content in the grain of the Acha variety has reached $12.3 \%$, of the Omsky 85 variety $-10.3 \%$, of the Payjazz variety $-9.8 \%$, of the Baltika variety - $9.9 \%$, of the Zhana variety $10.2 \%$, and of the Beatrice variety $-11.6 \%$. Thus, in addition to the available data on the possibility of obtaining barley grain that meets the brewing standards (32), the possibilities of obtaining high yield and high quality of grain from the studied varieties in the conditions of the northern foreststeppe of the Tyumen region has been demonstated.

\section{Conclusion}

In the experiment studying the variants of presowing seed treatment with the Lamador Pro fungicide and Rostok and Mival-Agro growth regulators, in terms of the complex indicator - the collection of protein from a unit area - the Lamador Pro + Rostok variant stood out: for the Acha variety, this indicator was $612 \mathrm{~kg} / \mathrm{ha}$, for the Abalak variety - $646 \mathrm{~kg} / \mathrm{ha}$. When studying the variants of treating the seeds and plants with micronutrient fertilizers, the best indicators were obtained in the variant with the use of Hydromix complex: for the Acha variety, the yield was $4.55 \mathrm{t} / \mathrm{ha}$, for the Abalak variety - $4.62 \mathrm{t} / \mathrm{ha}$, the protein content in the grain was 13.1 and $13.3 \%$, respectively. Five varieties of brewing barley were studied on different backgrounds of mineral fertilizers; in terms of yield, Omsky 85, Payjazz and Beatrice varieties surpassed the Acha standard by $0.36-0.73$ t/ha or $7-14 \%$. The protein content in grain of these varieties met the requirements for brewing barley (no more than 12\%). The obtained research results are recommended for implementation at the enterprises of the agro-industrial complex of the Tyumen region.

\section{Authors' contributions}

All authors contributed equally.

\section{Conflict of interests}

Authors do not have any conflict of interests to declare.

\section{References}

1. Loginov YP, Kazak AA, Yakubyshina LI. The Yield Rate and Quality of Tubers of Early Ripening Potato Varieties in the Conditions of Organic Agriculture of the Tyumen Region. Annals of Agri Bio Research. 2019;24(1):76-81. https://doi.org/2s2.0-85071655469

2. Kazak AA, Loginov YP. The yield rate and grain quality of midripening and mid-late valuable varieties of spring soft wheat bred in Siberia, in the northern forest-steppe of the Tyumen region. Annals of Agri Bio Research, 2019;24(2):174-82. https://doi.org/2-s2.0-8507612158

3. Kazak AA, Loginov YP, Eremin DI. Influence of mineral fertilizers on productivity and quality of wheat varieties seeds in the northern forest-steppe of the Tyumen region. Agricultural Science Euro-North-East. 2019;20(3):219-29. https://doi.org/10.30766/2072-9081.2019.20.3.219-229
4. Gryaznov AA. Golozernyiyachmen v kormleniisvinei [Hulless barley in pig feeding]. The regulatory issues in veterinary medicine. 2015;2:289-91.

5. Yakubyshina LI, Kazak AA, Loginov YP. Using the method of electrophoresis in farming seeds of barley varieties of grade Odessa 100. Ecology, Environment and Conservation Paper. 2018;24(2):1001-07.

6. GOST R 53900-2010 Feed barley. Technical conditions. Moscow: Standartinform; 2011.

7. GOST 28672-90 Barley. Requirements for procurement and delivery. Moscow: Standartinform. 2010.

8. GOST R 54895-2012 Grain. Method for determining nature. Moscow: Standartinform; 2013.

9. Loginov YP, Kazak AA, Yakubysina LI. Sortovye resursy yachmenya v Zapadnoi Sibiri [The varietal barley resources in Western Siberia]. Agricultural Bulletin of Urals. 2012;7(99):810.

10. Fomina MN. Sostoyanie i perspektivy selektsiizernofurazhnykh kultur $\mathrm{v}$ Severnom Zauralye [The state and prospects of breeding grain crops in Northern TransUrals]. Breeding crops for high genetic potential, yield and quality: Materials of the International Scientific and Practical Conference (Tyumen, June $24-27,2012$ ). Tyumen; 2012. p. 154-58.

11. Pershakov AY, Yakovlev VK, Belkina RI. Productivity and Protein Content in Barley Variety Grains In Northern TransUral Region. International scientific and practical conference "AgroSMART - Smart solutions for agriculture" (AgroSMART 2018). 2018. p. 559-63. https://doi.org/10.2991/agrosmart18.2018.104

12. Belkina RI, Vasilyev AA, Gubanov MV, Gubanova VM. Barley Productivity and Protein Content: Fertilization Effect. International scientific and practical conference "AgroSMART - Smart solutions for agriculture" (AgroSMART 2018). 2018. 8185. https://doi.org/10.2991/agrosmart-18.2018.16

13. Shamanin VP, Pototskaya IV, Shepelev SS, Pozherukova VE, Morgounov AI. The phenotyping of synthetic wheat aegilopstauschii genome in the conditions of southern foreststeppe of western Siberia. Asian Journal of Microbiology, Biotechnology and Environmental Sciences. 2017;19(1):153-59.

14. Nemchenko VV, Kekalo AY, Zargaryan NY, Tsypysheva MY Protravlivanie semyan - pervaya stupen polucheniya zashchishchennogo i produktivnogo agrotsenoza [Seed treatment is the first step for obtaining a secure and productive agrocenosis]. Plant Protection and Quarantine. 2014;3:22-24.

15. Laptiev AB, Kungurtseva OV. Novye preparaty dlya zashchity yarovykh zernovykh kultur otsemennoii pochvennoi infektsii [New products for protecting spring crops from the seed and soil infection]. Plant Protection and Quarantine. 2016;2:20-23.

16. Toropova EY, Zakharov AF. Predposevnaya podgotovka semyan yarovoi pshenitsy v usloviyakh resursosberegayushchikh tekhnologii [Presowing preparation of spring wheat seeds in the conditions of the resource-saving technologies]. Plant Protection and Quarantine. 2017;3:28-31.

17. Klyachina SL, Puzyreva ML, Akimova VA, Leonova NI, Burdenova TV, Zotikova AP.Vliyanie udobrenii, soderzhashchikh mikroelementy, na urozhainost i kachestvo selskokhozyaistvennykh kultur v usloviyakh Tomskoi oblasti [The effect of fertilizers containing microelements on the yield and the quality of crops in the conditions of the Tomsk region] Achievements of Agricultural Science and Technology. 2015;8:36-38

18. Eremin DI. Changes in the content and quality of humus in leached chernozems of the Trans-Ural forest-steppe zone under the impact of their agricultural use. Eurasian soil science. 45.https://doi.org/10.1134/S1064229316050033

19. Garkovenko AV, Radchenko VV, Ilnitskaya EV, Koshchaev AG, Shchukina IV, Bakharev AA, Sukhanova SF. Polymorphism of cattle microsatellite complexes. Journal of Pharmaceutical Sciences and Research. 2018;10(6):1545-51.

20. Sergeev AP, Lipatnikova TY, Voloshin EI. Mikroelementy v pochvakh Minusinskoi lesostepi Krasnoyarskogo kraya 
[Microelements in the soil of the Minusinsk forest-steppe in the Krasnoyarsk Krai]. Agrochemical Bulletin. 2017;2:48-50.

21. Eremin D, Eremina D. Influence of granulometric composition structure of anthropogenic- reformed soil on the ecology of infrastructure. Procedia Engineering. 2016;165:788-93.

22. Iglovikov A. The development of artificial phytocenosis in environmental construction in the far north. Procedia Engineering. 2016;165:800-05.

23. Zakirov ES, Sagitova RN, Gaysin IA, Tikhonova MA. Vliyanie khelatnykh mikroudobrenii na urozhainost i kachestvennye kharakteristiki rastenievodcheskoi produktsii [The effect of chelated micronutrient fertilizers on the yield and the quality characteristics of crop production]. Agrochemical Bulletin. 2014;4:9-13.

24. Kazak A, Loginov Y, Eremin D, Yashchenko S, Gaizatulin A Lisovskaya A. Medium-Early spring Wheat Cultivars Depending on The Level of Mineral Nutrition in The Northern Forest-Steppe of The Tyumen Region. Amazonia Investiga. 2020;9(25):143-52.

25. Karakotov SD, Denisov AD. Mikro- i organo-mineralnye udobreniya dlya predposevnoi obrabotki semyan, kornevykh i listovykh podkormok selskokhozyaistvennykh kultur [The micro- and organic-mineral fertilizers for presowing seed treatment and additional fertilization of the roots and leaves of the crops]. SchelkovoAgrokhim; 2014.

26. Gadimaliyeva G, Aminov N, Jahangirov A, Hamidov $H$, Abugalieva A, Shamanin V, Morgounov A. Productivity and disease resistance of primary hexaploid synthetic wheat lines and their crosses with bread wheat. Cereal Research Communications. 2018;46(2):355-64.

27. Lapochkina IF, Gainullin NR, Galinger DN, Lazareva EN, Baranova OA, Anisimova AV, Shamanin VP, Volkova GV, Gladkova EV, Vaganova OF. The development of the initial material of spring common wheat for breeding for resistance to stem rust (pucciniagraminis pers. F. Sp. Tritici), including the UG99 race, in Russia. Russian Journal of Genetics: Applied Research. 2017;7(3):308-17.

28. Likhenko IE, Zyryanova AF, Likhenko NI, Salina EA, Stasyuk AI, Shcherban AB. Study of the allelic composition of vrn-1 and ppd-1 genes in early-ripening and middle-early varieties of spring soft wheat in Siberia. Russian Journal of Genetics: Applied Research. 2015;5:198-207.
29. Geiger EY, Varlamova LD, Semenov VV, Pogodina VY, Sirotina YA. Mikroudobreniya na khelatnoi osnove: opyt i perspektivy ispolzovaniya [Chelated micronutrient fertilizers: the experience and the prospects of use]. Agrochemical Bulletin. 2017;2:23-26.

30. Savchenko AA, Belkina RI, Utkin AN. Primenenie mikroudobrenii, regulyatorov rosta i fungitsidov v tekhnologii vozdelyvaniya yarovoi pshenitsy [The use of micronutrient fertilizers, growth regulators and fungicides in the spring wheat cultivation technology]. Tyumen: TSAA; 2012.

31. Loginov YP, Kazak AA, Yakubyshina LI, Falaleeva TN, Yashchenko SN, Yarova ET. Breeding value of collection varieties of potato in the forest-steppe zone of the Tyumen region. Journal of Pharmaceutical Sciences and Research. 2018;10(1):377-80.

32. Opanasyuk IV. Kachestvo zerna pivovarennykh sortov yachmenya $\mathrm{v}$ usloviyakh Severnogo Zauralya [The brewing barley varieties grain quality in the conditions of Northern Trans-Urals]. Agrarian Bulletin of the Urals. 2012;2:13-15.

33. Torikov VE, Melnikova OV, Bakaev AA. Vliyani euslovii vozdelyvaniya na urozhainost yarovogo yachmenya [The effect of the cultivation conditions on the yield of spring barley]. Bulletin of the Bryansk State Agricultural Academy. 2009;3:38-43.

34. Vlasenko AN. Pivovarennyi yachmen v Zapadnoi Sibiri: metod. rekomendatsii [Malting barley in Western Siberia: methodical recommendations]. Novosibirsk; 2000.

35. Methodology for state variety testing of agricultural crops. Issue 1-2. Moscow: Kolos; 1983.

36. Corn. Analysis methods. Moscow: IPK Standards Publishing House; 2001.

37. GOST R 54895-2012 Grain. Method for determining nature. Moscow: Standartinform; 2013.

38. Dospekhov BA. Field experiment technique. Moscow: Agropromizdat; 1985.

39. Gorpinchenko TV. Otsenka kachestva sortov selskokhozyaistvennykh kultur kak syrya dlya pererabotki [Quality assessment of crop varieties as the raw materials for processing]. Moscow: RSAU-MAA; 2008. 